\title{
Perancangan Sistem Informasi dan Sarana Pelaporan Kasus Bullying Berbasis Web Menggunakan Teknologi Pemograman PHP dengan Framework Laravel
}

\author{
${ }^{1}$ Sutono*, ${ }^{2}$ Tri Widayanti, ${ }^{1}$ Bety Agustina Rahayu \\ ${ }^{1}$ Program Studi Keperawatan, STIKES Surya Global Yogyakarta \\ ${ }^{2}$ Program Studi Kesehatan Masyarakat, STIKES Surya Global Yogyakarta \\ *sutono@stikessuryaglobal.ac.id
}

\begin{abstract}
Abstrak
Bullying masih menjadi masalah sosial yang meresahkan. Kasus bullying yang terjadi pada siswa dengan jenjang SMA sudah banyak menimbulkan masalah baik fisik maupun psikologis. Bullying merupakan fenomena yang sangat banyak, mengakar, terwariskan dari generasi ke generasi. Seriusnya permasalahan bullying merupakan permasalahan besar bagi kita semua. Tingkat pengetahuan dan kepedulian baik guru, orangtua, tim pelayanan kesehatan, dan masyarakat Indonesia terhadap bullying ini dapat dikatakan masih rendah. Sistem informasi sangat dibutuhkan untuk manajemen dalam mengambil keputusan mengatasi masalah bully. Peneliti dalam penelitian ini membuat sebuah sistem yang dapat digunakan sebagai sarana penyampaian informasi dari siswa kepada sekolah. Pembuatan sistem ini didasarkan pada sistem yang mudah diakses, aman, dan dijamin kerahasiaan pengadunya. Sehingga produk ini dapat membantu sekolah mengidentifikasi kasus bullying di sekolah, siapa pelaku bullying, serta korban bullying, dengan begitu harapannya sekolah dapat menghentikan rantai kejadian bullying dan melakukan pencegahan kejadian bullying di sekolah. Skema pada penelitian ini adalah merancang sebuah website aduan kejadian bullying dan pemberian informasi. Model perancangan sistem yang digunakan dalam penelitian ini yaitu model prototype dan data dikumpulkan melalui observasi, wawancara dan studi pustaka. Bahasa pemrograman yang digunakan adalah PHP dan perangkat lunak untuk mendesain interface menggunakan Framework laravel. Pembuatan database menggunakan MySQL dengan aplikasi XAMMP.
\end{abstract}

Kata Kunci: Bullying, Sistem Informasi, website

Bullying is still a troubling social problem. Bullying cases that occur in high school students have caused many problems both physically and psychologically. Bullying is a phenomenon that is very much, rooted, passed down from generation to generation. The seriousness of bullying is a big problem for all of us. The level of knowledge and concern for teachers, parents, health service teams, and the Indonesian people towards bullying is still low. Information systems are needed for management in making decisions to overcome bullying problems. Researchers in this study created a system that can be used as a means of delivering information from students to schools. The creation of this system is based on a system that is easily accessible, secure, and guarantees the confidentiality of the complainants. So that this product can help schools identify cases of bullying in schools, who are the perpetrators of bullying, and victims of bullying, with the hope that schools can stop the chain of bullying events and prevent bullying at schools. The scheme in this study is to design a website that reports bullying and provides information. The system design model used in this study is a prototype model and data was collected through observation, interviews and literature study. The programming language used is PHP and software for designing interfaces using the laravel framework. Making a database using MySQL with the XAMMP application.

Keywords: Bullying, Information Systems, website

\section{PENDAHULUAN}

Sistem informasi merupakan suatu sistem yang menyediakan informasi untuk manajemen dalam mengambil keputusan. Pelaporan disebut juga sebagai aspirasi seseorang terhadap kejadian yang dirasakan meresahkan atau mengganggu ketenangan jiwa seseorang. Salah satu kasus yang harus mendapatkan perhatian pada siswa sekolah adalah kasus bullying. Bullying masih menjadi masalah sosial yang meresahkan. Tidak sedikit kasus bullying yang terjadi di lingkungan sekolah.

Kasus bullying yang terjadi pada siswa dengan jenjang SMA sudah banyak menimbulkan masalah baik fisik maupun psikologis, dimana 
usia SMA seharusnya sudah bisa berpikir untuk bertindak sesuai aturan dan norma yang ada. Kasus bullying merupakan fenomena yang sangat banyak, mengakar, terwariskan pada setiap generasi.

Data dari International Center for Research on Women (ICRW) melaporkan bahwa $84 \%$ siswa di Indonesia mengalami kekerasan di lingkungan sekolah. Data ini menunjukkan angka yang sangat memprihatinkan dan sangat mencoreng dunia pendidikan. Data yang didapatkan dari Komisi Perlindungan Anak Indonesia (KPAI) di tahun 2018, ditemukan kasus dibidang pendidikan sebanyak 161 kasus, $36(22,4 \%)$ merupakan kasus dengan anak korban kekerasan dan bullying, sedangkan kasus anak pelaku kekerasan dan bullying sebanyak 41 $(25,5 \%)$ (Eliasa, 2017).

Permasalahan bullying merupakan permasalahan besar bagi kita semua. Tingkat pengetahuan dan kepedulian baik guru, orangtua, tim pelayanan kesehatan, dan masyarakat Indonesia terhadap bullying ini dapat dikatakan masih rendah. Rendahnya tingkat kepedulian ini dikarenakan masih ada dan banyaknya kejadian bullying di sekolah, mengingat sekolah adalah tempat menimba ilmu dan memperoleh pendidikan. Meskipun banyak kejadian-kejadian bullying di SMA, namun pihak sekolah tidak dapat memiliki hasil rekaman atau pencatatan kejadian bullying, sehinga kejadian bullying tetap ada bahkan menjadi tradisi yang mengakar.

Bullying telah diakui sebagai pemicu dari masalah kesehatan bagi anak sekolah, karena mereka berhubungan dengan berbagai masalah penyesuaian termasuk kesehatan mental yang buruk dan perilaku kekerasan (Kusuma, 2016). Bullying berpeluang besar untuk ditiru, siswa yang melakukan bullying bisa terjadi setelah mereka sendiri pernah mendapatkan perlakuan bullyingmisalnya pernah disakiti oleh orang yang lebih kuat, teman sebaya atau yang lainya.

Hasil studi pendahuluan yang dilakukan di SMA 1 Pleret didapatkan data bahwa kepala sekolah mengatakan kasus perundungan atau bullying banyak terjadi, sudah terlaporakan tapi tidak terdokumentasi. Penanganan hanya melalui guru bimbingan konseling dan itupun jika hanya ada pelaporan.

Pada penelitian ini akan merancang sebuah website pelaporan kejadian bullying dan pemberian informasi. Tujuan dari penelitian ini ingin membantu mengidentifikasi kasus bullying yang ada di sekolah dalam sebuah sistem yang disediakan. Dalam sistem ini juga menyediakan informasi dalam website sebagai edukasi tentang bullying.

Berdasarkan latar belakang yang ada dirumuskan masalah bagaimana merancang sistem informasi dan sarana pelaporan kasus bullying berbasis web di SMA I Pleret?

\section{TINJAUAN PUSTAKA}

\section{A. Sistem Informasi}

\section{Definisi}

Sistem informasi merupakan suatu sistem yang menyediakan informasi untuk manajemen dalam mengambil keputusan, dimana sistem tersebut merupakan kombinasi dari orang-orang, teknologi informasi dan prosedurprosedur yang tergorganisasi. Sistem Informasi bersifat khas karena dibangun di atas 3 (tiga) bidang yaitu: komputer, manajemen dan bisnis. Sistem informasi antara lain terdiri dari pemrograman, jaringan komputer, basis data, pengembangan software, dan sebagainya (Hudiarto, 2017).

\section{B. Pelaporan}

Laporan merupakan pemberitahuan telah sedang atau akan terjadi peristiwa yang diduga tindak pidana. Waktu pelaporan dapat dilaporkan setiap waktu asal belum kadaluarsa (sesuai pasal 78 KUHP)

\section{Kasus Bullying}

Bullying dalam bahasa Indonesia dikenal sebagai penindasan atau risak, dimana bullying merupakan segala bentuk penindasan atau kekerasan yang dilakukan dengan sengaja oleh satu atau sekelompok orang yang lebih kuat atau berkuasa terhadap orang lain dengan tujuan untuk menyakiti dan dilakukan secara terus menerus (Wardhana, 2015).

\section{Web}

Menurut Simarmata (2012), aplikasi web adalah sebuah sistem informasi yang mendukung interaksi pengguna melalui antarmuka berbasis web.

\section{METODE}

Metode yang digunakan dalam penelitian ini adalah analisis dan perancangan sistem. Model perancangan sistem yang digunakan yaitu model prototype dan data dikumpulkan melalui observasi, wawancara, dan studi pustaka. Bahasa pemrograman yang digunakan adalah PHP dan perangkat lunak untuk mendesain interface menggunakan Framework laravel. Pembuatan database menggunakan MySQL dengan aplikasi XAMMP.

HASIL DAN PEMBAHASAN

Tahap Analisa 
Tahapan ini dirumuskan kebutuhan pengembangan sistem yang menjabarkan fungsionalitas dari sistem yang akan dikembangkan dan dibutuhkan oleh pengguna sistem. Fungsionalitas sistem disini merupakan pernyataan bahwa sistem memiliki kemampuan untuk melakukan aktifitas yang diminta oleh pengguna. Hasil analisis kebutuhan sistem adalah mempertimbangkan batasan-batasan dari aktifitas yang diharapkan oleh pengguna yang terdiri atas kegiatan

1. Komunikasi

Melakukan observasi dan wawancara pada bagian kesiswaan, siswa dan bagian bimbingan konseling.

\section{Planning}

Pada tahap perencanaan sistem ini menjelaskan tentang estimasi tugas yang akan dilakukan, resiko-resiko yang dapat terjadi saat pembu atan sistem, sumber daya yang diperlukan dalam pembuatan sistem, produk kerja yang ingin dihasilkan serta penjadwalan kerja yang akan dilaksanakan.

Tahapan Perancangan

Perancangan sistem merupakan kegiatan menyusun rancangan sistem informasi dan sarana pelaporan kasus bullying berbasis web di SMA N 1 Pleret secara konseptual logikal dengan menggunakan alat-alat dan bahasa grafis yang memodelkan sistem yang akan dikembangkan. Rancangan sistem terdiri atas sebagai berikut :

1. Rancangan proses adalah model proses aktifitas sistem informasi dan sarana pelaporan kasus bullying berbasis web di SMA N 1 Pleret, yaitu di tunjukkan pada gambar 1.

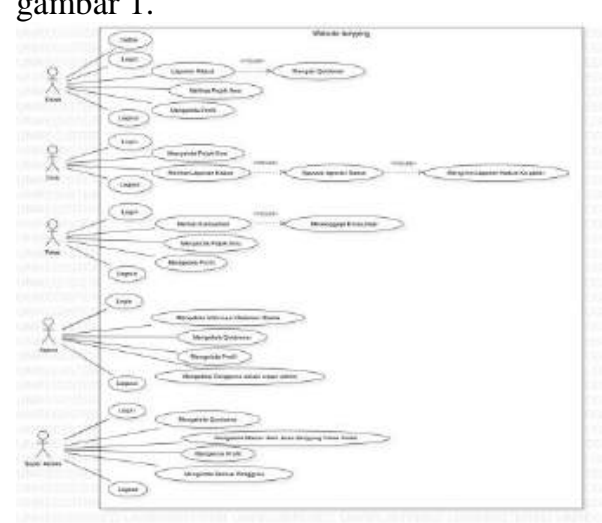

Gambar 1 Rancangan Use Case

2. Rancangan basisdata adalah model struktur dan hubungan entitas simpanan data pada sistem informasi dan sarana pelaporan kasus bullying berbasis web di SMA N 1 Pleret, yaitu di tunjukkan pada Gambar 2.

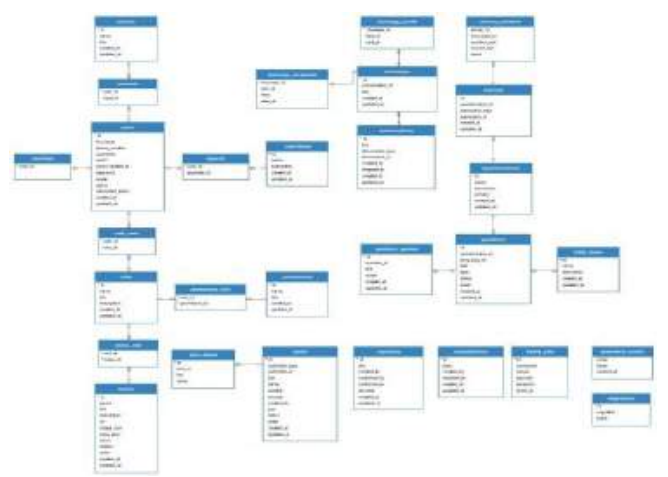

Gambar 2 rancangan Diagram Relasi Sistem informasi dan Sarana Pelaporan

3. Rancangan antarmuka adalah model dialog interaktif antara pengguna dan informasi dan sarana pelaporan kasus bullying berbasis web di SMA N 1 Pleret, yaitu di tunjukkan pada Gambar 3 sampai dengan sekian.

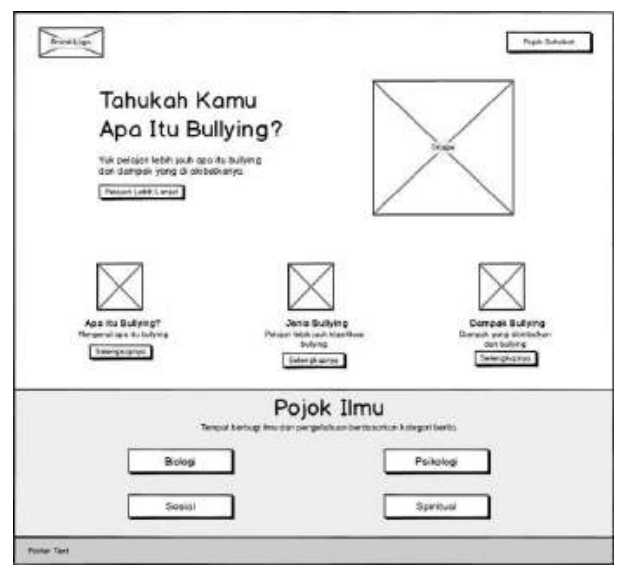

Gambar 3 rancangan menu tampilan pada halaman utama website

Gambar 3 menunjukan rancangan halaman utama website. Pada tampilan utama terdiri dari pengetahuan tentang bullying, tombol pojok sahabat ( login), pojok ilmu. bagian pengetahuan tentang bullying menampilkan tentang definisi bulliying, jenis bullying dan dampak bulliying. Isi dari menu menu ini diinput dari halaman superadmin pada menu master. 


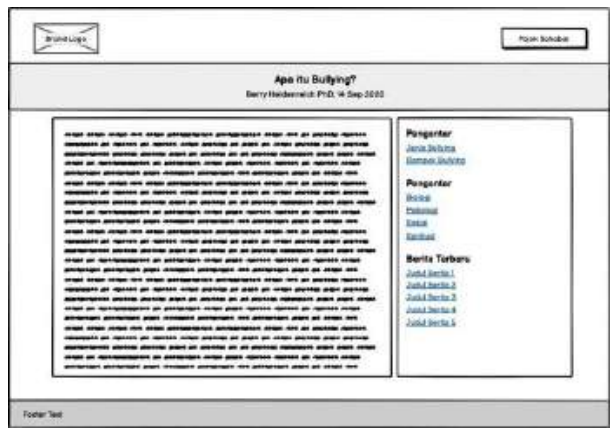

Gambar 4 rancangan halaman pengetahuan tentang bullying pada halaman utama website

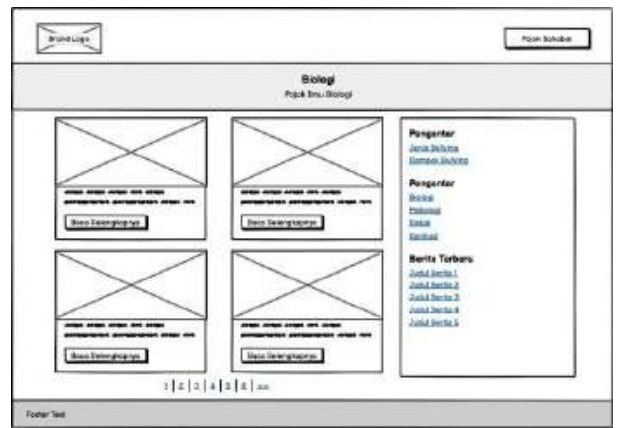

Gambar 5 rancangan halaman pojok ilmu pada halaman utama web

Gambar 5 menunjukan rancangan halaman pojok ilmu. Pada halaman pojok ilmu, menampilkan pengetahuan dari berbagai bidang keilmuan yaitu biologi, psikologi, sosial, spiritual. halaman ini untuk memberikan pengetahuan kepada user baik pengetahuan dasar mapun dampak bulliying dilihat dari berbagai aspek.

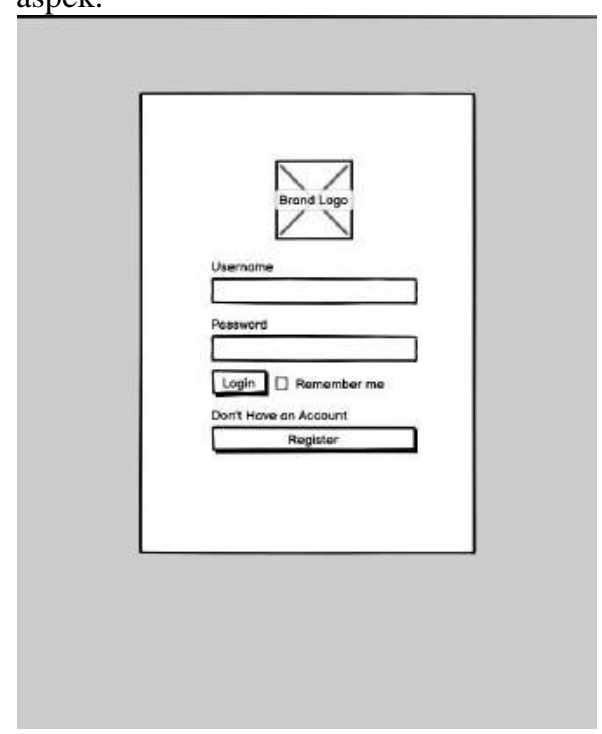

Gambar 6 Rancangan Menu Login

Menu login digunkan oleh semua pengguna untuk login ke akun masingmasing pengguna. Untuk memampilkan menu login, pengguna diarahkan untuk klik menu atau tulisan pojok sahabat pada halaman utama web.

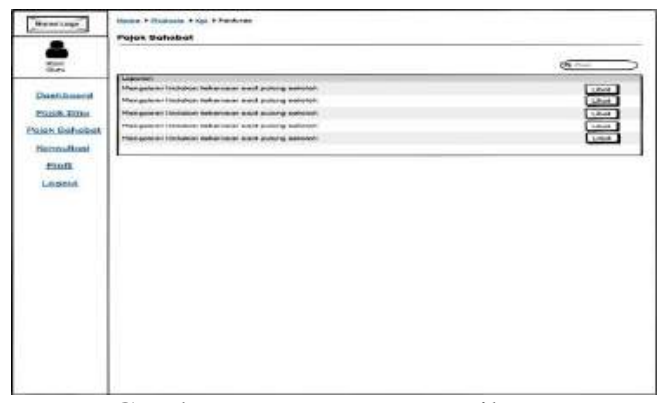

Gambar 7 rancangan tampilan menu pada halaman guru

Gambar 7 menunjukan rancangan tampilan menu pada halaman guru. Pada halaman guru terdiri dari menu dashboard, pojok ilmu, pojok sahabat, konsultasi, profil dan logout. Pada menu konsultaasi guru melihat dan menerima laporan bulliying kemudian laporan dikirim ke pakar untuk ditanggapi.

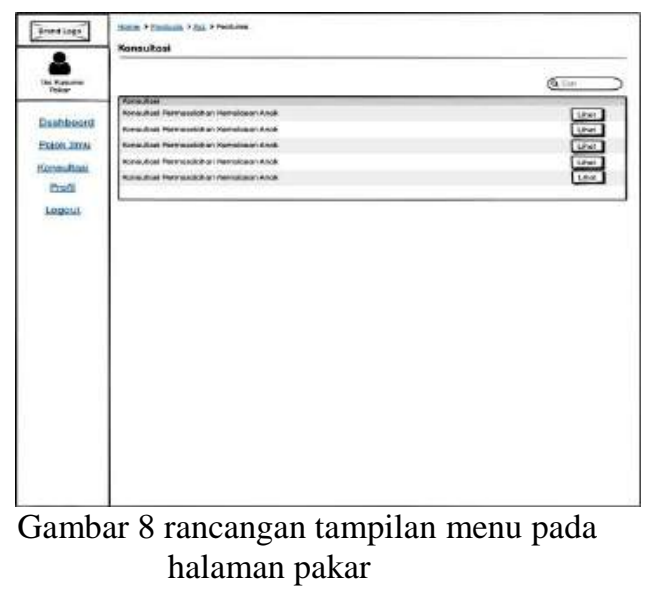

Pada gambar 8 adalah gambar rancangan menu pada halaman pakar. Ada beberapa pakar, ada pakar psikologi, pakar sosial, pakar biologi, pakar spiritual dalam masing masing pakar ada menu Dashboard, pojok ilmu, Konsultasi, profil, logout. Para pakar melihat dan menanggapi laporan/ konsultasi pada menu konsultasi.

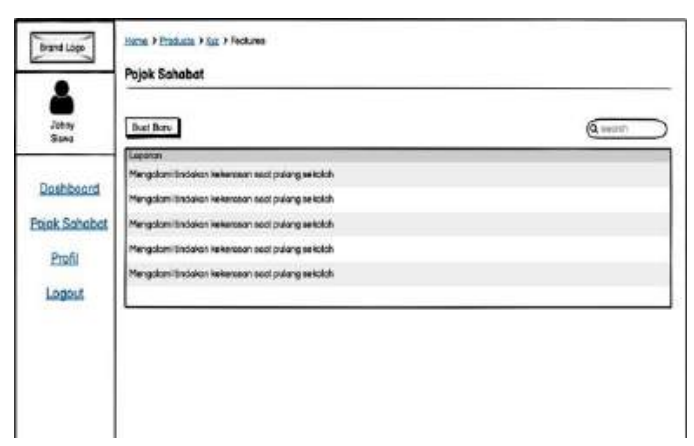

Gambar 9 Rancangan Jendela Siswa 
Gambar 9 menunjukan ancangan menu pada halaman siswa: menu dashboard, pojok sahabat, profil, logout. Pada menu dashboard siswa dapat melihat berbagai informasi di pojok ilmu. Pada menu pojok sahabat digunakan siswa untuk membuat laporan bullying. Menu profil digunakan siswa untuk membuat profil akun. Menu logout digunakan untuk logout dari akun.

\section{KESIMPULAN}

Berdasarkan analisis yang telah dilakukan terhadap permasalahan dari analisis yang telah dibuat, maka dapat ditarik kesimpulan yang diperlukan untuk pengembangan sistem ke tahap yang lebih kompleks.

1. Sistem berjalan yang digunakan oleh sekolah SMA N 1 Pleret dalam menangani pelaporan bullying masih mengunakan cara yang manual, sehingga menyulitkan para warga sekolah untuk langsung melaporkan pengaduan bullying.

2. Kesulitan dan kendala yang dihadapi dalam sistem berjalan yang selama ini dialami adalah belum adanya wadah pelaporan kasus bullying yang dianggap aman. Oleh sebab itu dibutuhkan suatu sistem informasi yang dapat di akses dengan mudah bagi seluruh warga sekolah agar dapat menjadi media untuk melaporkan, serta pihak sekolah dapat dengan cepat juga menangani hal tersebut.

3. Perancangan sistem informasi dan sarana pelaporan kasus bullying berbasis webdi SMA N 1 Pleret merupakan suatu cara untuk mendapatkan efisiensi dan efektifitas informasi dapat dikirim dan diterima secara cepat dan tepat sehingga dapat mencapai tujuan yang diinginkan.

\section{DAFTAR PUSTAKA}

1. Azwar, S. (2012) Reliabilitas dan Validitas. 4th edn. Yogyakarta: Pustaka Pelajar.

2. Chan, VN. (2012) Aplikasi Berbasis Web untuk Pengendali Pengiriman Gas PT Surya Biru Murni Acetylene Balikpapan. Tesis UPN "Veteran" Yogyakarta

3. Coloroso (2007) Stop Bullying. Jakarta: PT Serambi Ilmu Semesta.

4. Darmalina, B. (2014) Perilaku School Bullying Di SD N Grindang Hargomulyo Kokap Kulon Progo Yogyakarta. Universitas Negeri Yogyakarta.

5. Darmawan (2017) 'Fenomena Bullying (Perisakan) Di Lingkungan Sekolah', Jurnal Kependidikan, 1(2), pp. 253-262. Available at: https://media.neliti.com/media/publications/2 23185-bullying-phenomena-in-schoolsetting.pdf.

6. Djamal, M. (2016) Fenomena Kekerasan di
Sekolah. 1st edn. Edited by Ratih. Yogyakarta: Pustaka Pelajar.

7. Kusuma, M. P. (2016) Perilaku School Bullying Pada Siswa Sekolah Dasar Negeri Delegan 2, Dinginan, Sumberharjo, Prambanan, Sleman, Yogyakarta. Universitas Negeri Yogyakarta.

8. Maria, R. A. A. (2018) Motif Siswa Melakukan Bullying Terhadap Guru Baru Di Sekolah Menengah Kejuruan (SMK) Wiworotomo Purwokerto. IAIN Purwokerto.

9. Petiprin, A. (2016) Nursing Theori Roy. Available at: http://www.nursingtheory.org/theories-and-models/royadaptation-model.php (Accessed: 16 March 2019).

10.Prasetyo, A. (2011) Bullying Di Sekolah Dan Dampaknya Bagi Masa Depan Anak. 4th edn. El-Tarbawi.

11.Pratomo, Yudha (2019) APJII: Jumlah Pengguna Internet di Indonesia Tembus 171 Juta Jiwa. Jakarta: Kompas.com

12.Sari, Y. P. and Azwar, W. (2017) 'Bullying bullying', 10(November), pp. 333-367.

13.Sejiwa (2008) Bullying A-Z. Available at: http://sejiwa.org/a-z/.

14.Simarmata, Janner (2012) Rekayasa Web. Yogyakarta: ANDI

15.Sugiyanto (2015) 'Karakteristik Anak Usia SD', pp.

16. Available at: http://staff.uny.ac.id/sites/default/files/tmp/K arakteristik Siswa SD.pdf

17.Tion (2018) Dampak Bullying Yang Dirasakan Korban dan Pelaku. Available at: http://www.thebullybook.com/dampakbullying-yang-dirasakan-korban-dan-pelaku/.

18. Wardhana, K. (2015) Stop Bullying Campaign Buku Panduan Melawan Bullying. 1st edn. Edited by M. Susant. Jakarta.

19. Wiyani (2012) Save Our Children From School Bullying. Yogyakarta: Ar-Ruzz Media. 